\title{
Dehydrochlorination of Intermediates in the Production of Vinyl Chloride over Lanthanum Oxide-Based Catalysts
}

\author{
Alwies W. A. M. van der Heijden · Ad J. M. Mens • \\ René Bogerd · Bert M. Weckhuysen
}

Received: 15 December 2007 / Accepted: 8 February 2008/Published online: 28 March 2008

(C) The Author(s) 2008

\begin{abstract}
Lanthanum oxide-based catalysts are active in the elimination of $\mathrm{HCl}$ from $\mathrm{C}_{2} \mathrm{H}_{5} \mathrm{Cl}, 1,2-\mathrm{C}_{2} \mathrm{H}_{4} \mathrm{Cl}_{2}$ and 1,1,2- $\mathrm{C}_{2} \mathrm{H}_{3} \mathrm{Cl}_{3}$ leading to the formation of their respective chlorinated ethenes. An oxygen-rich catalytic surface may form $\mathrm{CO}, \mathrm{CO}_{2}$ and $\mathrm{C}_{2} \mathrm{HCl}$ as side products, whereas with chlorine-rich catalytic surfaces a stable product distribution is achieved with $100 \%$ selectivity towards the formation of ethenes, such as the valuable $\mathrm{C}_{2} \mathrm{H}_{3} \mathrm{Cl}$ intermediate.
\end{abstract}

Keywords Dehydrochlorination - Heterogeneous catalysis · Lanthanum oxide - Chlorinated ethanes · Gas phase IR

\section{Introduction}

With an annual production of 45 million tons, chlorine is one of the most important chemicals for numerous commercial products [1]. The reaction with chlorine activates hydrocarbons, making them suitable as building blocks for organic synthesis. Moreover, chlorinated hydrocarbons (CHCs) are used as organic solvents and are persistent, making them heatresistant and relatively inert. On the other hand, the same properties which make these compounds useful in industry make them harmful when emitted into the environment. In the last decades, it was found that $\mathrm{CHCs}$ contribute to various environmental effects, such as acid rain formation, ozone layer depletion and the greenhouse effect [2-4]. Also, many

A. W. A. M. van der Heijden - A. J. M. Mens · R. Bogerd

B. M. Weckhuysen $(\square)$

Inorganic Chemistry and Catalysis Group, Department

of Chemistry, Faculty of Science, Utrecht University,

Sorbonnelaan 16, 3584 CA Utrecht, The Netherlands

e-mail: b.m.weckhuysen@uu.nl
CHCs are carcinogenic and toxic. Even though the better understanding of the effects of these substances has greatly reduced the use in commercial applications, they are still used and produced in large quantities in industry [5].

More than one third of all chlorine is used for the production of polyvinyl chloride (PVC), the most produced plastic in the world after polyethylene (PE) $[1,5] . \mathrm{C}_{2} \mathrm{H}_{3} \mathrm{Cl}$ is the monomer of PVC and is industrially prepared from $\mathrm{C}_{2} \mathrm{H}_{4}$ and chlorine. $\mathrm{C}_{2} \mathrm{H}_{4}$ is chlorinated into $1,2-\mathrm{C}_{2} \mathrm{H}_{4} \mathrm{Cl}_{2}$ via oxychlorination and direct chlorination described by Reaction Equations (1) and (2), respectively. 1,2- $\mathrm{C}_{2} \mathrm{H}_{4} \mathrm{Cl}_{2}$ is then thermally cracked into $\mathrm{C}_{2} \mathrm{H}_{3} \mathrm{Cl}$ as shown in Reaction Equation (3). The oxychlorination process is used to lower chlorine consumption by recycling $\mathrm{HCl}$ from the cracking of $1,2-\mathrm{C}_{2} \mathrm{H}_{4} \mathrm{Cl}_{2}$, though selectivity towards $1,2-$ $\mathrm{C}_{2} \mathrm{H}_{4} \mathrm{Cl}_{2}$ is lower than for the direct chlorination process. Overall, the reactions are performed at relatively high selectivity ( $>98 \%$ ), but the scale of the process result in the formation of large quantities of by-products [6]. Various chlorinated $\mathrm{C}_{1}$ and $\mathrm{C}_{2}$ are formed in side- reactions and are separated from $1,2-\mathrm{C}_{2} \mathrm{H}_{4} \mathrm{Cl}_{2}$ as the so-called light and heavy ends. Regulation on the production and emission [2-4] of CHCs has enforced efficient degradation of excess CHCs, which is done in most cases by incineration [7]. However, because of the high heat resistance of the CHCs and possible formation of furans and dioxins, a high temperature $\left(>1,000{ }^{\circ} \mathrm{C}\right)$ is needed for this process, making it costly. In addition, incineration results in loss of feedstock.

$$
\begin{aligned}
& \mathrm{C}_{2} \mathrm{H}_{4}+1 / 2 \mathrm{O}_{2}+2 \mathrm{HCl} \rightarrow 1,2-\mathrm{C}_{2} \mathrm{H}_{4} \mathrm{Cl}_{2}+\mathrm{H}_{2} \mathrm{O} \\
& \mathrm{C}_{2} \mathrm{H}_{4}+\mathrm{Cl}_{2} \rightarrow 1,2-\mathrm{C}_{2} \mathrm{H}_{4} \mathrm{Cl}_{2} \\
& 1,2-\mathrm{C}_{2} \mathrm{H}_{4} \mathrm{Cl}_{2} \rightarrow \mathrm{C}_{2} \mathrm{H}_{3} \mathrm{Cl}+\mathrm{HCl}
\end{aligned}
$$

Research efforts have been made on methods to efficiently convert $\mathrm{CHCs}$ at low temperature into non-hazardous or 
re-usable products. Catalytic (hydro)dechlorination can be categorized by three types of systems: noble metals, transition metal oxides and basic oxides. In the case of noble metals, poisoning of the catalyst by chlorine remains a difficult issue to overcome [8-13]. Even though transition metal oxides are very active for the dechlorination of CHCs, the chlorination of the oxide may result in the formation of toxic volatile transition metal oxychlorides [14-21]. The basic oxides have proven to be stable active materials for the conversion of CHCs [22-34]. In previous work, lanthanum oxide-based catalysts were found to have the highest destructive capacity for the catalytic destruction of chlorinated $\mathrm{C}_{1}$ and have been studied in detail in our group [29-31, 33, 34]. However, activity towards both chlorinated $\mathrm{C}_{1}$ and $\mathrm{C}_{2}$ is important for conversion of the light ends mixture formed in $\mathrm{C}_{2} \mathrm{H}_{3} \mathrm{Cl}$ production.

$1,1-\mathrm{C}_{2} \mathrm{H}_{2} \mathrm{Cl}_{2}$, which is the monomer for the production of polyvinylidene chloride ( $\mathrm{PVDC}$ ), is prepared from the dehydrochlorination of $1,1,2-\mathrm{C}_{2} \mathrm{H}_{3} \mathrm{Cl}_{3}$ using alkaline solutions [35]. Actually, in most cases $1,1,2-\mathrm{C}_{2} \mathrm{H}_{3} \mathrm{Cl}_{3}$ is used to produce 1,1- $\mathrm{C}_{2} \mathrm{H}_{2} \mathrm{Cl}_{2}$, since sufficient quantities are formed during the production of $\mathrm{C}_{2} \mathrm{H}_{3} \mathrm{Cl}$. Also, the cracking of 1,2$\mathrm{C}_{2} \mathrm{H}_{4} \mathrm{Cl}_{2}$ to $\mathrm{C}_{2} \mathrm{H}_{3} \mathrm{Cl}$ is a non-catalytic dehydrochlorination reaction. Not many heterogeneous catalysts are known for the dehydrochlorination of chlorinated ethanes, mainly because of low selectivity and chlorine poisoning. In fact, alumina is active for this reaction and has been studied because dehydrochlorination is an undesirable side-reaction in the oxychlorination of ethene into $1,2-\mathrm{C}_{2} \mathrm{H}_{4} \mathrm{Cl}_{2}$, which is catalyzed by $\mathrm{CuCl}_{2} / \gamma-\mathrm{Al}_{2} \mathrm{O}_{3}[36,37]$. Therefore, catalytic dehydrochlorination of chlorinated ethanes is not only interesting from a waste conversion point of view as an active dehydrochlorination catalyst could be used in the preparation steps towards $\mathrm{C}_{2} \mathrm{H}_{3} \mathrm{Cl}$ as well. Here, we report for the first time on such new active dehydrochlorination catalyst based on lanthanum oxides, which leads to the selective formation of $\mathrm{C}_{2} \mathrm{H}_{3} \mathrm{Cl}$ when starting from $1,2-\mathrm{C}_{2} \mathrm{H}_{4} \mathrm{Cl}_{2}$.

\section{Experimental}

\subsection{Materials and Characterization}

Commercial samples of $\mathrm{La}_{2} \mathrm{O}_{3}$ (Acros Organics, 99.99\%) were used without additional purification. $\mathrm{LaOCl}$ was synthesized by a precipitation process using $\mathrm{LaCl}_{3} \cdot 7 \mathrm{H}_{2} \mathrm{O}$ (Acros Organics, 99.99\%) as precursor and a $\mathrm{NH}_{4} \mathrm{OH}$ (Merck, $25 \mathrm{wt} \%$ in water p.a.) solution. The obtained gel $\left(\mathrm{La}(\mathrm{OH})_{2} \mathrm{Cl}\right)$ was filtered, washed and dried at $120{ }^{\circ} \mathrm{C}$ and heated at $550{ }^{\circ} \mathrm{C}$ in pure $\mathrm{N}_{2}$ (Linde, $\geq 99.999 \%$ ) for $6 \mathrm{~h}$. The phase composition of $\mathrm{La}_{2} \mathrm{O}_{3}$ and $\mathrm{LaOCl}$ after the reaction as a function of time with $1,1,2-\mathrm{C}_{2} \mathrm{H}_{3} \mathrm{Cl}_{3}$ was determined using X-ray diffraction (XRD) and X-ray photoelectron spectroscopy (XPS). XRD measurements were performed at ambient conditions with a Bruker-AXS D8 diffractometer equipped with a $\mathrm{Co}_{\mathrm{K} \alpha 1,2}$ source. The XPS spectra were acquired using a Perkin-Elmer (PHI) model 5500 spectrometer. All XPS spectra were obtained using samples in the form of pressed wafers.

\subsection{Flow Gas Experiments}

The activity experiments for the dehydrochlorination of $\mathrm{C}_{2} \mathrm{H}_{5} \mathrm{Cl}$ (Aldrich, $\geq 99.7 \%$ ), 1,2- $\mathrm{C}_{2} \mathrm{H}_{4} \mathrm{Cl}_{2}$ (Acros Organics, $\geq 99.8 \%$ ) and 1,1,2- $\mathrm{C}_{2} \mathrm{H}_{3} \mathrm{Cl}_{3}$ (Acros Organics, $\geq 98 \%$ ) were performed in a tubular fixed-bed quartz reactor. The catalyst bed consisted of $0.5 \mathrm{~g} \mathrm{LaOCl}$ or $\mathrm{La}_{2} \mathrm{O}_{3}$ pressed in a 200-500 $\mu \mathrm{m}$ sieve fraction, pretreated in $10 \mathrm{~mL} / \mathrm{min} \mathrm{He}$ (Linde, $\geq 99.996 \%$ ) at $550{ }^{\circ} \mathrm{C}$. The flow was regulated by Brooks $0-100 \mathrm{~mL}$ automatic mass flow controllers. To find the initial reaction temperature, the reaction was carried out from 50 to $400{ }^{\circ} \mathrm{C}$ using a $25 \mathrm{~mL} / \mathrm{min} 3-4 \mathrm{vol} \%$ reactant/ He flow. In the case of $1,2-\mathrm{C}_{2} \mathrm{H}_{4} \mathrm{Cl}_{2}$ and $1,1,2-\mathrm{C}_{2} \mathrm{H}_{3} \mathrm{Cl}_{3}$, the flow was generated by flowing $\mathrm{He}$ through a bubbler containing the liquid reactant. The $\mathrm{C}_{2} \mathrm{H}_{5} \mathrm{Cl}$ feed was generated from $2 \mathrm{~mL} / \mathrm{min}_{2} \mathrm{C}_{5} \mathrm{Cl}$ and $23 \mathrm{~mL} / \mathrm{min} \mathrm{He}$. Once stabilized, the flow was led over the reactor bed, consisting of $\mathrm{LaOCl}$ or $\mathrm{La}_{2} \mathrm{O}_{3}$. The temperature of the reactor was raised from 50 to $400{ }^{\circ} \mathrm{C}$ in steps of $10{ }^{\circ} \mathrm{C}$. The heating ramp was $3.3^{\circ} \mathrm{C} / \mathrm{min}$, and after each step, the temperature was held constant for $5 \mathrm{~min}$. The composition of the reactor effluent was analyzed by a Siemens Maxum Edition 2 gas chromatograph with a sampling time of $240 \mathrm{~s}$. In the case of $1,1,2-\mathrm{C}_{2} \mathrm{H}_{3} \mathrm{Cl}_{3}$, the reactions were also performed at constant temperature of $400{ }^{\circ} \mathrm{C}$ over $\mathrm{La}_{2} \mathrm{O}_{3}$ and $\mathrm{LaOCl}$. The composition of the reaction mixture was analyzed with time.

\subsection{IR Experiments}

During the flow gas experiments with 1,1,2-trichloethane over $\mathrm{La}_{2} \mathrm{O}_{3}$, several products were detected which could not be assigned by GC. To complement the GC data, the reaction of 1,1,2-trichloethane on $\mathrm{La}_{2} \mathrm{O}_{3}$ was monitored in situ by IR. A static vacuum quartz cell was employed and all IR spectra were recorded using a Perkin Elmer 2000 spectrometer with a resolution of $4 \mathrm{~cm}^{-1}$. $\mathrm{La}_{2} \mathrm{O}_{3}$ (Acros Organics, $99.99 \%$ ) was pressed into a self-supporting wafer $\left(2 \mathrm{~cm}^{2}\right)$, and activated in situ prior to the IR measurements in dynamic vacuum at $550{ }^{\circ} \mathrm{C}$ overnight. $1,1,2-\mathrm{C}_{2} \mathrm{H}_{3} \mathrm{Cl}_{3}$ (Acros Organics, 98\%) was evaporated by injection via a septum into an evacuated flask, which was connected to the vacuum system. After pretreatment, 1,1,2- $\mathrm{C}_{2} \mathrm{H}_{3} \mathrm{Cl}_{3}$ (30 mbar) was introduced into the cell, which was then closed. The wafer was positioned in a separate heated part 
of the cell, enabling the measurement of gas phase IR spectra. The temperature was raised from 100 to $400{ }^{\circ} \mathrm{C}$ in steps of $50{ }^{\circ} \mathrm{C}$. After each step the temperature was held constant during which gas phase spectra were recorded.

\section{Results and Discussion}

\subsection{Temperature Programmed Reaction Studies on the Catalyst Activity and Selectivity}

The effluent composition of the temperature programmed dehydrochlorination reactions over $\mathrm{LaOCl}$ is shown in Fig. 1. In the case of $\mathrm{C}_{2} \mathrm{H}_{5} \mathrm{Cl}$ and $1,2-\mathrm{C}_{2} \mathrm{H}_{4} \mathrm{Cl}_{2}, 100 \%$ selectivity is observed towards $\mathrm{C}_{2} \mathrm{H}_{4}$ and $\mathrm{C}_{2} \mathrm{H}_{3} \mathrm{Cl}$, respectively (Reaction Equations (4) and (5)). 1,1,2- $\mathrm{C}_{2} \mathrm{H}_{3} \mathrm{Cl}_{3}$ is converted into several products. A significantly lower initial reaction temperature is observed for chloroethane compared to $1,2-\mathrm{C}_{2} \mathrm{H}_{4} \mathrm{Cl}_{2}$ and $1,1,2-\mathrm{C}_{2} \mathrm{H}_{3} \mathrm{Cl}_{3}$. It has been established that the cleavage of the $\mathrm{C}-\mathrm{Cl}$ bond typically precedes the removal of a $\mathrm{H}$ atom [38, 39]. Furthermore, it has been shown that the initial reaction rate for the dehydrochlorination of chlorinated ethanes increases with an increasing number of chlorine atoms [40]. It should be noted, however, that this trend was established based on mono-, di- and tri-substituted chloroethanes with all chlorine atoms on the same carbon atom. With more $\mathrm{C}-\mathrm{Cl}$ bonds on the same carbon atom in a chlorinated ethane molecule, the $\mathrm{C}-\mathrm{Cl}$ bonds become more polarized. As a result, the $\mathrm{C}-\mathrm{Cl}$ bonds are more susceptible to cleavage. Instead, $\mathrm{C}-\mathrm{Cl}$ bonds on both carbon atoms may stabilize the polarization of the $\mathrm{C}-\mathrm{Cl}$ bonds, which explains the higher initial temperature of reaction of $1,2-\mathrm{C}_{2} \mathrm{H}_{4} \mathrm{Cl}_{2}$ and 1,1,2- $\mathrm{C}_{2} \mathrm{H}_{3} \mathrm{Cl}_{3}$ with respect to $\mathrm{C}_{2} \mathrm{H}_{5} \mathrm{Cl}$.

The main product for the dehydrochlorination of 1,1,2- $\mathrm{C}_{2} \mathrm{H}_{3} \mathrm{Cl}_{3}$ is $1,1-\mathrm{C}_{2} \mathrm{H}_{2} \mathrm{Cl}_{2}$ and in addition $\mathrm{C}_{2} \mathrm{H}_{3} \mathrm{Cl}$ and cis-1,2- $\mathrm{C}_{2} \mathrm{H}_{2} \mathrm{Cl}_{2}$ are formed. The formation of $\mathrm{C}_{2} \mathrm{H}_{3} \mathrm{Cl}$ implies that $\mathrm{Cl}_{2}$ elimination occurs. This reaction is, however, energetically highly unfavourable and is not expected to proceed. A possible explanation would be that a different product is co-eluting with $\mathrm{C}_{2} \mathrm{H}_{3} \mathrm{Cl}$. Therefore, the product assigned by the $\mathrm{GC}$ as $\mathrm{C}_{2} \mathrm{H}_{3} \mathrm{Cl}$ has been labelled as $\mathrm{X}$ in Figs. 1 and 2. Chlorine and hydrogen atoms can be removed from the reactant molecule via two pathways of $\mathrm{HCl}$ elimination, shown in Reaction Scheme 1. The formation of $1,1-\mathrm{C}_{2} \mathrm{H}_{2} \mathrm{Cl}_{2}$ (Scheme 1, Reaction a) is favoured over the reaction towards 1,2- $\mathrm{C}_{2} \mathrm{H}_{2} \mathrm{Cl}_{2}$ (Scheme 1, Reaction b). In addition, no formation of trans-1,2- $\mathrm{C}_{2} \mathrm{H}_{2} \mathrm{Cl}_{2}$ (Scheme 1, Reaction c) was detected. At $400{ }^{\circ} \mathrm{C}$, trace amounts of $\mathrm{CO}$ and $\mathrm{CO}_{2}$ were detected. Blank experiments were also performed and no significant product formation was observed, which rules out non-catalytic gas phase
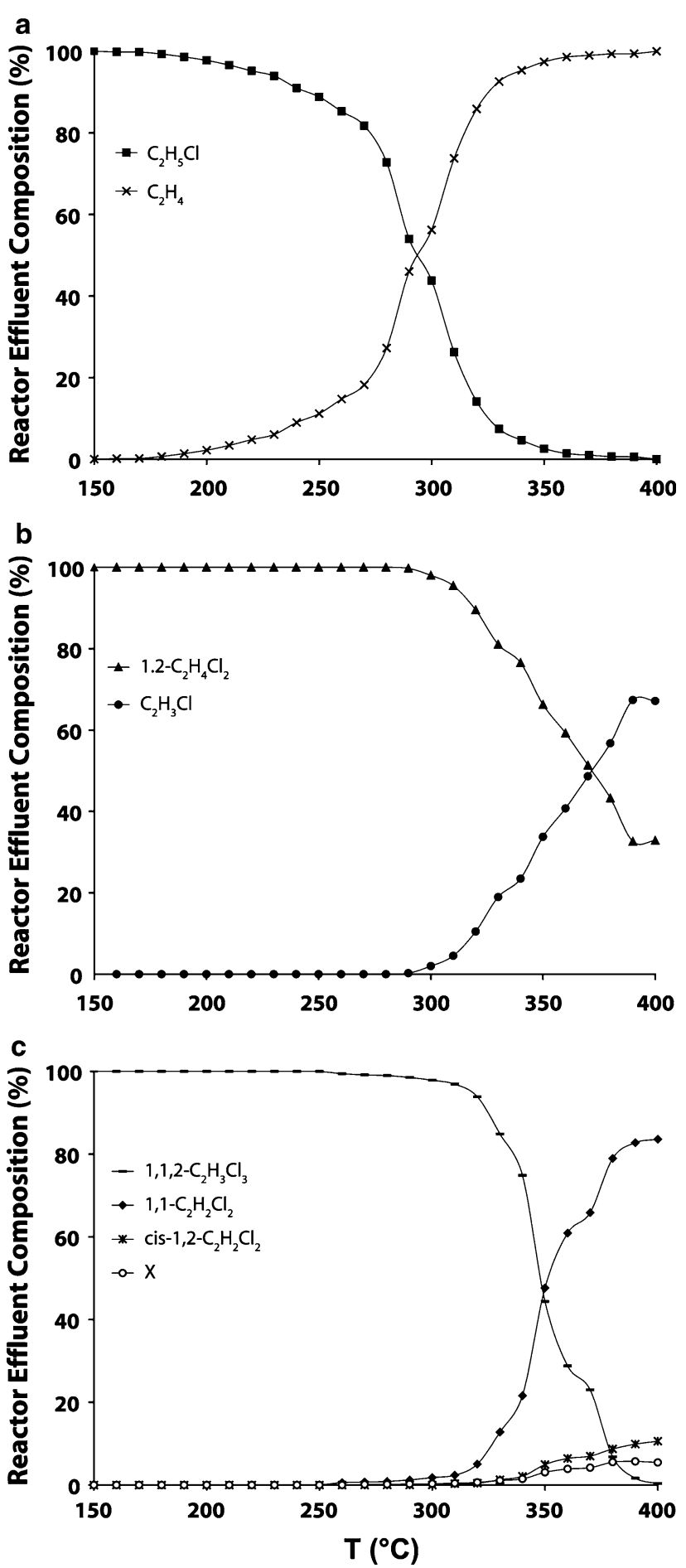

Fig. 1 Effluent composition for the dehydrochlorination of (a) $\mathrm{C}_{2} \mathrm{H}_{5} \mathrm{Cl}$, (b) $1,2-\mathrm{C}_{2} \mathrm{H}_{4} \mathrm{Cl}_{2}$ and (c) $1,1,2-\mathrm{C}_{2} \mathrm{H}_{3} \mathrm{Cl}_{3}$ over $\mathrm{LaOCl}$ as a function of temperature. ( $\mathrm{GHSV}=2,000 \mathrm{~h}^{-1}$, inlet concentration: $\left[\mathrm{C}_{2} \mathrm{H}_{5} \mathrm{Cl}\right]=3.7 \mathrm{vol} \%, \quad\left[1,2-\mathrm{C}_{2} \mathrm{H}_{4} \mathrm{Cl}_{2}\right]=3.4 \mathrm{vol} \%$ and $[1,1,2-$ $\left.\mathrm{C}_{2} \mathrm{H}_{3} \mathrm{Cl}_{3}\right]=3.2 \mathrm{vol} \%, \mathrm{X}=$ product unassigned based on $\mathrm{GC}$ )

reactions. Based on these results, it is concluded that $\mathrm{LaOCl}$ is an active catalyst for the dehydrochlorination of chlorinated ethanes. 


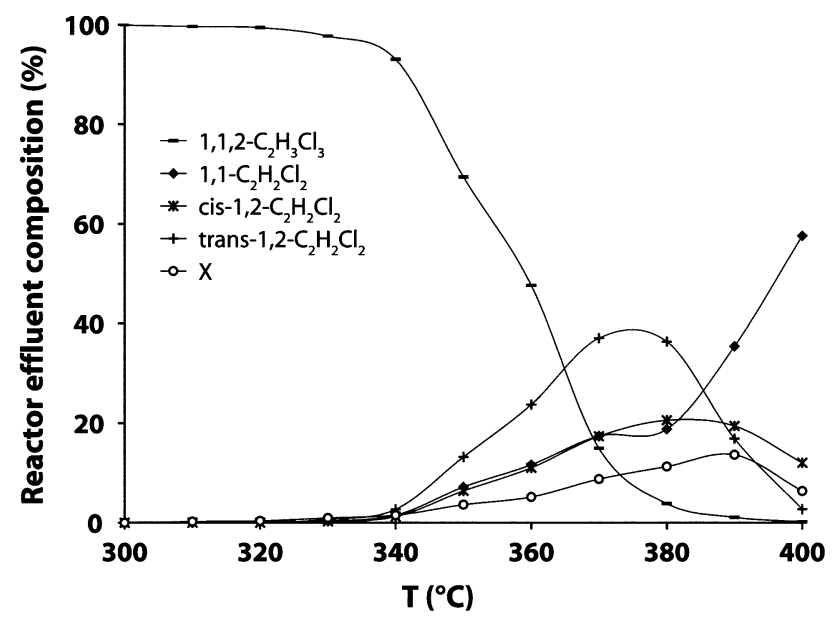

Fig. 2 Effluent composition for the dehydrochlorination of 1,1,2$\mathrm{C}_{2} \mathrm{H}_{3} \mathrm{Cl}_{3}$ over $\mathrm{La}_{2} \mathrm{O}_{3}$ as a function of temperature. (GHSV $=2,000$ $\mathrm{h}^{-1}$, inlet concentration: $\left[1,1,2-\mathrm{C}_{2} \mathrm{H}_{3} \mathrm{Cl}_{3}\right]=3.2 \mathrm{vol} \%, \mathrm{X}=$ product unassigned based on GC)<smiles>ClC=CCCl</smiles>

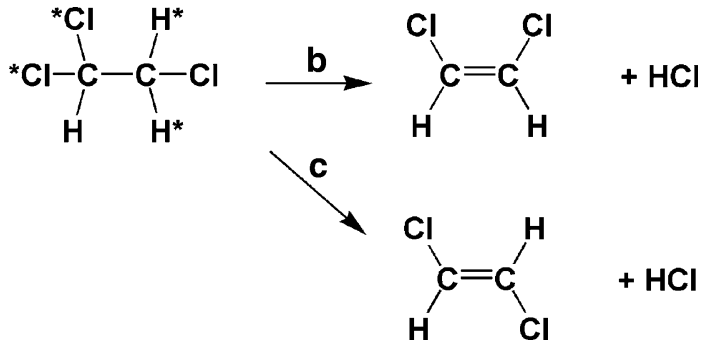

Scheme 1 Reaction pathways for the dehydrochlorination of 1,1,2$\mathrm{C}_{2} \mathrm{H}_{3} \mathrm{Cl}_{3}$ into (a) $1,1-\mathrm{C}_{2} \mathrm{H}_{2} \mathrm{Cl}_{2}$, (b) cis-1,2- $\mathrm{C}_{2} \mathrm{H}_{2} \mathrm{Cl}_{2}$ and (c) trans-1,2$\mathrm{C}_{2} \mathrm{H}_{2} \mathrm{Cl}_{2}$

$$
\begin{aligned}
& \mathrm{CH}_{2} \mathrm{Cl}-\mathrm{CH}_{3} \rightarrow \mathrm{CH}_{2}=\mathrm{CH}_{2}+\mathrm{HCl} \\
& \mathrm{CH}_{2} \mathrm{Cl}-\mathrm{CH}_{2} \mathrm{Cl} \rightarrow \mathrm{CH}_{2}=\mathrm{CHCl}+\mathrm{HCl}
\end{aligned}
$$

The dehydrochlorination of chlorinated ethanes over heterogeneous catalysts is catalyzed by three types of active sites: acidic, basic or dual sites [41]. It has been shown that for the dehydrochlorination of 1,1,2-trichloroethane, the selectivity towards the 1,1- and 1,2-product are influenced by the acid-base properties of the catalyst [41]. Control of the chlorination degree of the catalyst is crucial to tune the acid-base properties and optimize the performance of the catalyst when converting mixtures of chlorinated $\mathrm{C}_{1}$ and $\mathrm{C}_{2}$. In previous work, it was shown that the acid-base properties of lanthanum oxide-based catalysts are a key factor for the activation of $\mathrm{C}-\mathrm{Cl}$ and $\mathrm{C}-\mathrm{H}$ bonds in chlorinated $\mathrm{C}_{1}[33,34]$. Hence, the degree of chlorination may also be of influence on the selectivity of the dehydrochlorination of chlorinated $\mathrm{C}_{2}$. Therefore, the reaction with 1,1,2- $\mathrm{C}_{2} \mathrm{H}_{3} \mathrm{Cl}_{3}$ was repeated with $\mathrm{La}_{2} \mathrm{O}_{3}$, which contains weaker $\mathrm{La}^{3+}$ Lewis acid sites. The reactor effluent composition was analyzed throughout the experiment, as shown in Fig. 2. In addition to the products observed over $\mathrm{LaOCl}$, trans-1,2- $\mathrm{C}_{2} \mathrm{H}_{2} \mathrm{Cl}_{2}$ is detected. However, as the temperature increases the selectivity towards $1,1-\mathrm{C}_{2} \mathrm{H}_{2} \mathrm{Cl}_{2}$ increases, while it decreases towards the other products. Low concentrations of $\mathrm{CO}$ and $\mathrm{CO}_{2}$ were detected as in the case of $\mathrm{LaOCl}$. Also, small amounts of two products were detected which could not be assigned based on the GC results. Even though these products could not be identified, the retention times indicate that these compounds are CHCs. Therefore, the same response factor as for the other CHCs is assumed to be valid for these unknown products.

\subsection{In Situ IR Studies on the Catalyst Activity and Selectivity}

The flow-gas experiments indicate that $\mathrm{La}_{2} \mathrm{O}_{3}$ and $\mathrm{LaOCl}$ catalyze the dehydrochlorination of chlorinated ethanes and that the acid-base properties of the catalyst directly influence the selectivity. However, the assignment of the products is difficult with gas chromatography only. Therefore, the gas phase composition of the temperature programmed reaction on $\mathrm{La}_{2} \mathrm{O}_{3}$ in a vacuum cell was monitored using IR spectroscopy to complement the GC results. The recorded spectra are shown in Fig. 3. In the spectral regions $2,250-2,400$ and $1,350-1,900 \mathrm{~cm}^{-1}$, the strong bands of ambient $\mathrm{CO}_{2}$ and $\mathrm{H}_{2} \mathrm{O}$, respectively, were removed by spectroscopic software. Figure 3 a illustrates the increase and decrease of the bands in the gas phase spectra as a function of temperature during the experiment. In Fig. 3b, the spectrum of the reactant at room temperature (RT) is shown together with that of Spectrum 11 from Fig. 3a. Spectrum 11 was chosen for the assignment of the bands of the products, because all the bands which are observed during the experiment are present in this spectrum.

The assignment of the bands based on reference spectra is shown in Table 1 [42]. The products that are formed throughout the experiment are $1,1-\mathrm{C}_{2} \mathrm{H}_{2} \mathrm{Cl}_{2}$, cis-1,2$\mathrm{C}_{2} \mathrm{H}_{2} \mathrm{Cl}_{2}$, trans-1,2- $\mathrm{C}_{2} \mathrm{H}_{2} \mathrm{Cl}_{2}, \mathrm{C}_{2} \mathrm{HCl}, \mathrm{CO}$ and $\mathrm{CO}_{2}$. Specific bands were chosen, which possesses high intensity and minimal overlap with other bands, to derive the relative ratios of the products as a function of temperature as shown in Fig. 3a. The spectra show that $\mathrm{C}_{2} \mathrm{H}_{2} \mathrm{Cl}_{2}$ derivatives are formed simultaneously at $200{ }^{\circ} \mathrm{C}$ (Fig. 3a, spectrum 4).

As the temperature increases (Fig. 3a, spectrum 5-9), the intensity of the chlorinated ethene bands increases with maximum intensity at $250{ }^{\circ} \mathrm{C}$ (Fig. 3a, spectrum 9). Further increase of the temperature results in a decrease in intensity 
Fig. 3 (a) Gas phase IR spectra recorded during the dehydrochlorination of 1,1,2$\mathrm{C}_{2} \mathrm{H}_{3} \mathrm{Cl}_{3}$ over $\mathrm{La}_{2} \mathrm{O}_{3}$ as a function of temperature: (0) reactant at $\mathrm{RT}$, (1) $5 \mathrm{~min}$ at $100{ }^{\circ} \mathrm{C}$, (2) $5 \mathrm{~min}$ at $150{ }^{\circ} \mathrm{C}$, (3) 5 min at $200{ }^{\circ} \mathrm{C}$, (4-6) 5, 10 and $25 \mathrm{~min}$ at $250{ }^{\circ} \mathrm{C},(7-9) 5,10$ and $25 \mathrm{~min}$ at $300{ }^{\circ} \mathrm{C},(10-12)$ 5,10 and $25 \mathrm{~min}$ at $350{ }^{\circ} \mathrm{C}$, (13-15) 5, 10 and $75 \mathrm{~min}$ at $400{ }^{\circ}$ C. (b) Spectrum (0) and (11) used for band assignment of products
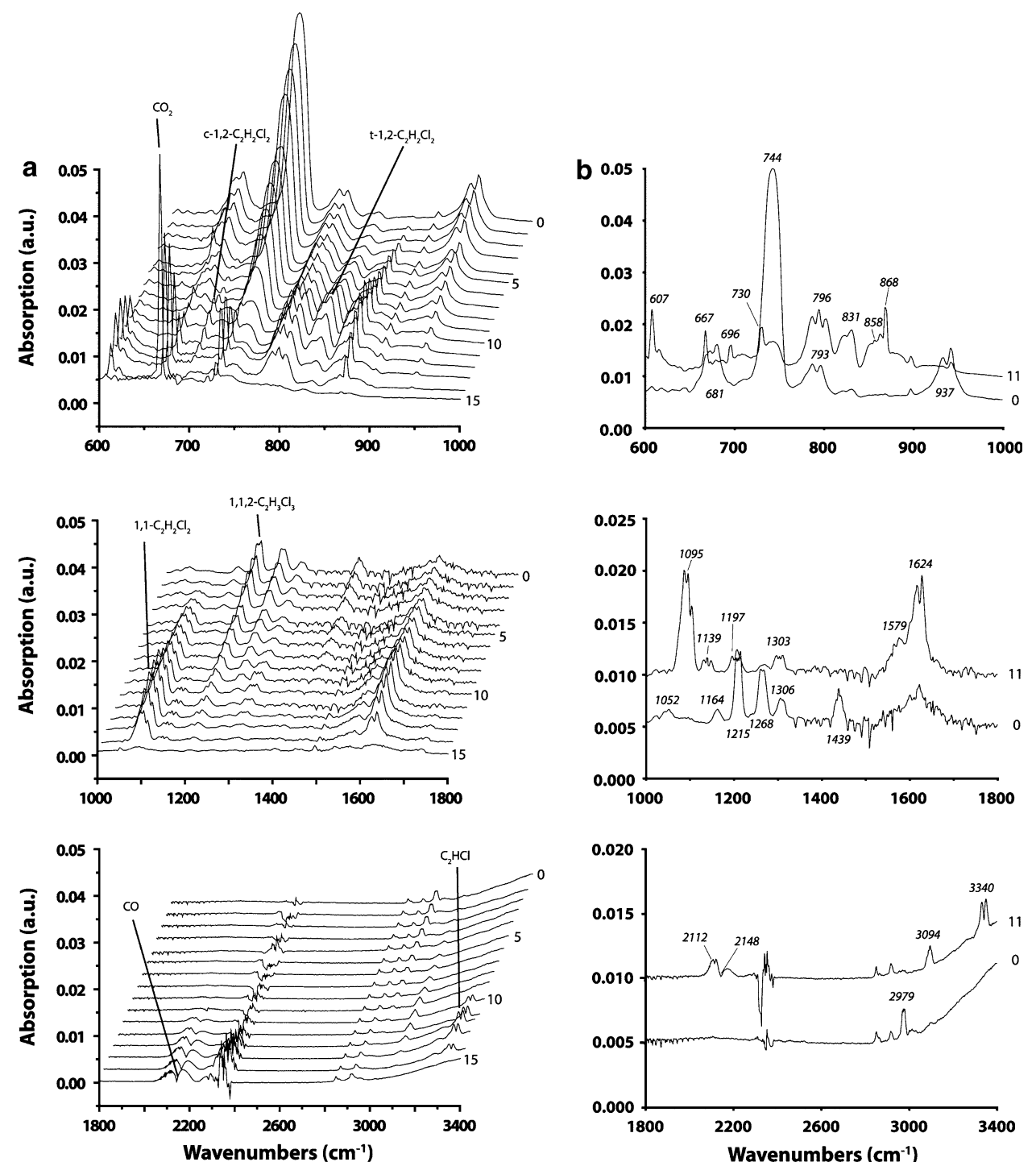

of the bands assigned to cis/trans-1,2- $\mathrm{C}_{2} \mathrm{H}_{2} \mathrm{Cl}_{2}$. The intensity of the $1,1-\mathrm{C}_{2} \mathrm{H}_{2} \mathrm{Cl}_{2}$ band, however, remains constant. The decrease in intensity of the bands of the 1,2-derivatives is accompanied by the formation of $\mathrm{CO}, \mathrm{CO}_{2}$ and $\mathrm{C}_{2} \mathrm{HCl}$ (Fig. 3a, spectrum 10). The formation of $\mathrm{C}_{2} \mathrm{HCl}$ indicates that a second dehydrochlorination reaction may occur resulting in the formation of a $\mathrm{C} \equiv \mathrm{C}$ bond. At $350{ }^{\circ} \mathrm{C}$, a band becomes visible at $730 \mathrm{~cm}^{-1}$, for which a reference could not be found. Strong absorption at this position is characteristic for $\mathrm{C}-\mathrm{Cl}$ stretch vibrations. When the temperature reaches $400{ }^{\circ} \mathrm{C}$, the bands of $\mathrm{C}_{2} \mathrm{HCl}$ and $1,1-\mathrm{C}_{2} \mathrm{H}_{2} \mathrm{Cl}_{2}$ also decrease and a strong increase in intensity of the $\mathrm{CO}_{2}$ band is observed. The formation of $\mathrm{CO}$ and $\mathrm{CO}_{2}$ is characteristic products for destructive adsorption of $\mathrm{CHCs}$. After more than $1 \mathrm{~h}$ of reaction, only $\mathrm{CO}$ and $\mathrm{CO}_{2}$ are detected. These results show that high temperatures should be avoided to prevent undesirable secondary reactions.
No bands indicative of $\mathrm{C}_{2} \mathrm{H}_{3} \mathrm{Cl}$ were observed in the spectra. The other products which were detected during the temperature programmed flow-gas experiment over $\mathrm{La}_{2} \mathrm{O}_{3}$ (Fig. 2), namely $1,1-\mathrm{C}_{2} \mathrm{H}_{2} \mathrm{Cl}_{2}$ and cis/trans-1,2- $\mathrm{C}_{2} \mathrm{H}_{2} \mathrm{Cl}_{2}$, were also observed in the in situ IR experiment. Therefore, based on these spectra it is proposed that the product which coelutes with $\mathrm{C}_{2} \mathrm{H}_{3} \mathrm{Cl}$ is $\mathrm{C}_{2} \mathrm{HCl}$. The dehydrochlorination of $1,1,2-\mathrm{C}_{2} \mathrm{H}_{3} \mathrm{Cl}_{3}$ proceeds at relatively low temperature. At higher temperature, two secondary reactions of the chlorinated ethenes are favorable; a second elimination of $\mathrm{HCl}$ or destructive adsorption. The former results in the formation of $\mathrm{C}_{2} \mathrm{HCl}$. The latter results in the breaking of the $\mathrm{C}-\mathrm{C}$ bond and formation of $\mathrm{CO}$ and $\mathrm{CO}_{2}$ via exchange of oxygen and chlorine atoms. The 1,2- $\mathrm{C}_{2} \mathrm{H}_{2} \mathrm{Cl}_{2}$ derivatives are more susceptible to the secondary reactions than $1,1-\mathrm{C}_{2} \mathrm{H}_{2} \mathrm{Cl}_{2}$. It should be noted that no significant amounts of $\mathrm{CO}$ and $\mathrm{CO}_{2}$ were detected during the flow-gas experiments. A possible reason 
Table 1 Assignment of the gas phase IR bands in spectrum recorded after $10 \mathrm{~min}$ of conversion of $1,1,2-$ trichloethane over $\mathrm{La}_{2} \mathrm{O}_{3}$ at $350{ }^{\circ} \mathrm{C}$ shown in Fig. 3b. (vs = strong, $\mathrm{s}=$ strong)

\begin{tabular}{|c|c|c|c|c|c|c|}
\hline Spectrum 11 & $1,1-\mathrm{C}_{2} \mathrm{H}_{2} \mathrm{Cl}_{2}$ & c- $1,2-\mathrm{C}_{2} \mathrm{H}_{2} \mathrm{Cl}_{2}$ & $\mathrm{t}-1,2-\mathrm{C}_{2} \mathrm{H}_{2} \mathrm{Cl}_{2}$ & $\mathrm{C}_{2} \mathrm{HCl}$ & $\mathrm{CO}_{2}$ & $\mathrm{CO}$ \\
\hline 607 & $603(\mathrm{~s})$ & & & & & \\
\hline 667 & & & & & $667(s)$ & \\
\hline 696 & & 697 (vs) & & & & \\
\hline 796 & 800 (vs) & & & & & \\
\hline 831 & & & 828 (vs) & & & \\
\hline 858 & & 857 (vs) & & & & \\
\hline 868 & 875 (vs) & & & & & \\
\hline 1095 & 1095 (vs) & & & & & \\
\hline 1139 & 1139 (s) & & & & & \\
\hline 1197 & & & $1200(\mathrm{~s})$ & & & \\
\hline 1303 & & $1303(\mathrm{~s})$ & & & & \\
\hline 1579 & & $1574(\mathrm{~s})$ & & & & \\
\hline 1624 & 1627 (vs) & & & & & \\
\hline 2112 & & & & $2110(s)$ & & \\
\hline 2148 & & & & & & 2144 (vs) \\
\hline 3094 & & & $3090(\mathrm{~s})$ & & & \\
\hline 3340 & & & & 3340 (vs) & & \\
\hline
\end{tabular}

for this may be the different nature of the experiments; the IR experiments are in a closed cell as opposed to the flow-gas experiment in which the reactant has a limited residence time.

\subsection{Catalyst Behaviour}

The temperature programmed flow-gas experiment over $\mathrm{La}_{2} \mathrm{O}_{3}$ suggests there is an induction period during which the selectivity changes. This is supported by the in situ IR experiments. Moreover, no bands indicative of $\mathrm{HCl}$ were found in the gas phase spectra. It is known that $\mathrm{La}_{2} \mathrm{O}_{3}$ and $\mathrm{LaOCl}$ can be chlorinated into a pure $\mathrm{LaCl}_{3}$ phase using $\mathrm{HCl}$. The $\mathrm{HCl}$ reacts with the basic oxygen sites according to Reaction Equation (6). During the dehydrochlorination of chlorinated ethanes, $\mathrm{HCl}$ may either be re-adsorbed or the $\mathrm{H}$ and $\mathrm{Cl}$ atom are abstracted directly by the La-O couple and remain on the surface. Either way, the catalytic surface will change which may affect the activity and selectivity. The stability of $\mathrm{LaOCl}$ and $\mathrm{La}_{2} \mathrm{O}_{3}$ materials for the dehydrochlorination of $1,1,2-\mathrm{C}_{2} \mathrm{H}_{3} \mathrm{Cl}_{3}$ was tested in a flow-gas experiment at $400{ }^{\circ} \mathrm{C}$. The reactor effluent composition as a function of time is shown in Fig. 4. The experiment over $\mathrm{La}_{2} \mathrm{O}_{3}$ was stopped prematurely because the reactor became plugged. The experiments show that over $\mathrm{La}_{2} \mathrm{O}_{3}$, an induction period precedes a stable conversion and product distribution. The same products which were detected during the temperature programmed reactions are formed. The two unknown products, labelled $\mathrm{x} 1$ and $\mathrm{x} 2$, are formed at higher concentrations than during the temperature programmed experiments and are therefore included in Fig. 4. In the case of $\mathrm{LaOCl}$, the induction period is not observed. After the induction period, the product distribution in the constant temperature experiments is similar for both $\mathrm{LaOCl}$ and $\mathrm{La}_{2} \mathrm{O}_{3}$. Although coke formation was observed, no significant loss of activity occurs in the experiments. $\mathrm{LaOCl}$ has proven to be a more stable catalyst with high selectivity towards chlorinated ethenes.
Fig. 4 Effluent composition for the dehydrochlorination of 1,1,2- $\mathrm{C}_{2} \mathrm{H}_{3} \mathrm{Cl}_{3}$ over (a) $\mathrm{La}_{2} \mathrm{O}_{3}$ and (b) $\mathrm{LaOCl}$ at $400{ }^{\circ} \mathrm{C}$ as a function of time.

$\left(\mathrm{GHSV}=2,000 \mathrm{~h}^{-1}\right.$, inlet concentration: $[1,1,2-$

$\left.\mathrm{C}_{2} \mathrm{H}_{3} \mathrm{Cl}_{3}\right]=3.2 \mathrm{vol} \%$,

$\mathrm{x}_{\mathrm{n}}=$ product unassigned based on GC and IR)
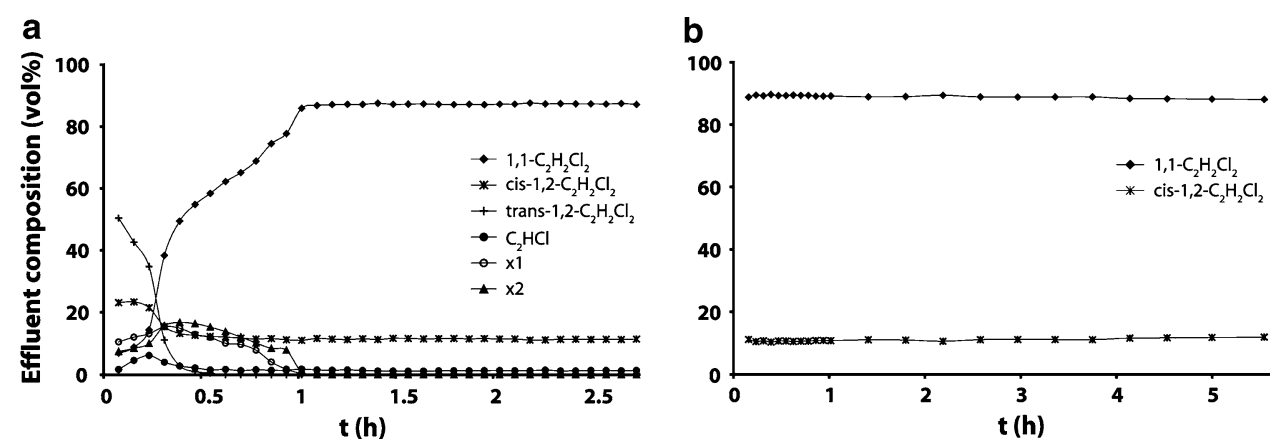
$\mathrm{La}-\mathrm{O}-\mathrm{La}(\mathrm{s})+\mathrm{HCl}(\mathrm{g}) \rightarrow \mathrm{La}-\mathrm{OH}(\mathrm{s})+\mathrm{Cl}-\mathrm{La}(\mathrm{s})$

Even though the $\mathrm{GC}$ is not calibrated for $\mathrm{HCl}$ and $\mathrm{H}_{2} \mathrm{O}$, these products are visible in the chromatogram at low retention times. The intensities of the peaks assigned to $\mathrm{HCl}$ and $\mathrm{H}_{2} \mathrm{O}$ are shown in Fig. 5 as a function of time. The hydroxyl groups formed after $\mathrm{HCl}$ elimination can react into both $\mathrm{HCl}$ and $\mathrm{H}_{2} \mathrm{O}$. Initially, $\mathrm{H}_{2} \mathrm{O}$ is eliminated from the oxygen-rich catalytic surface according to Reaction Equation (7). As the reaction proceeds, less hydroxyl groups are available and more chlorine is present on the surface. As a result, elimination of $\mathrm{HCl}$ from the surface becomes more favourable. The reaction time at which $\mathrm{HCl}$ formation becomes more dominant than $\mathrm{H}_{2} \mathrm{O}$ formation, is also when the product distribution becomes stable. Therefore, it is proposed that a specific degree of chlorination of the catalyst material results in steady-state conversion of chlorinated ethanes. It should be noted that a small amount of $\mathrm{H}_{2} \mathrm{O}$ is probably still formed together with $\mathrm{HCl}$ once the product distribution has stabilized, but due to overlap of the $\mathrm{H}_{2} \mathrm{O}$ and $\mathrm{HCl}$ peak, the intensity of the $\mathrm{H}_{2} \mathrm{O}$ peak is considered zero.

$2 \mathrm{La}-\mathrm{OH}(\mathrm{s}) \rightarrow \mathrm{H}_{2} \mathrm{O}(\mathrm{g})+\mathrm{La}-\mathrm{O}-\mathrm{La}(\mathrm{s})$

If a specific chlorination degree is needed for steady-state conversion, the catalyst materials used in the constant temperature experiments should possess similar surface compositions. To verify this, the $\mathrm{LaOCl}$ and $\mathrm{La}_{2} \mathrm{O}_{3}$ catalyst were characterized before and after reaction with 1,1,2trichloethane using XPS and XRD. The XRD results, as shown in Fig. 6, provide information on the bulk phase composition of the catalyst materials. Before reaction, the characteristic diffraction patterns of $\mathrm{LaOCl}$ and $\mathrm{La}_{2} \mathrm{O}_{3}$ are observed (Fig. 6a and c, respectively). The diffractogram of $\mathrm{La}_{2} \mathrm{O}_{3}$ after approximately $3 \mathrm{~h}$ of reaction at $400{ }^{\circ} \mathrm{C}$ is shown in Fig. 6b. The peaks observed after reaction show that during reaction the crystalline $\mathrm{La}_{2} \mathrm{O}_{3}$ phase has been converted into a pure crystalline $\mathrm{LaOCl}$ phase. Even though the peaks are much broader in the amorphous $\mathrm{LaOCl}$ catalyst material, the similarity is straightforward. The dehydrochlorination of 1,1,2-trichloethane at $400{ }^{\circ} \mathrm{C}$ over $\mathrm{LaOCl}$ was performed for ca. $6 \mathrm{~h}$, which is over two

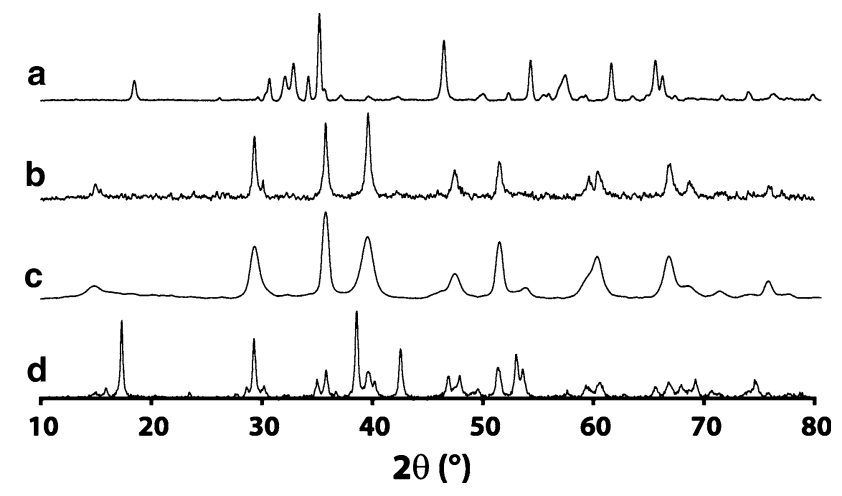

Fig. 6 X-ray diffractograms of $\mathrm{La}_{2} \mathrm{O}_{3}$ and $\mathrm{LaOCl}$ before (a and c, respectively) and after (b and d, respectively) the dehydrochlorination of $1,1,2-\mathrm{C}_{2} \mathrm{H}_{3} \mathrm{Cl}_{3}$ at $400{ }^{\circ} \mathrm{C}$, as shown in Fig. 4

times as long as in the case of $\mathrm{La}_{2} \mathrm{O}_{3}$. The pattern of the $\mathrm{LaOCl}$ phase is partially preserved after reaction. However, a second phase is present, which was assigned as $\mathrm{LaCl}_{3} \cdot 3 \mathrm{H}_{2} \mathrm{O}$. The peaks at $2 \theta=17.3,29.2,38.5,42.5$ and $46.9^{\circ}$ and their relative intensities are characteristic of $\mathrm{LaCl}_{3} \cdot 3 \mathrm{H}_{2} \mathrm{O}$. It is uncertain whether $\mathrm{LaOCl}$ is converted into $\mathrm{LaCl}_{3} \cdot 3 \mathrm{H}_{2} \mathrm{O}$ directly or into $\mathrm{LaCl}_{3}$, which becomes hydrated when it is exposed to air prior to the XRD measurement. Either way, the bulk phase of both $\mathrm{La}_{2} \mathrm{O}_{3}$ and $\mathrm{LaOCl}$ has become chlorinated during the constant temperature reactions. Chlorination of the bulk phase is also observed during the destructive adsorption and catalytic destruction of chlorinated $C_{1}$ [29-33]. This is caused by the solid-state diffusion of oxygen and chlorine atoms between the catalytic surface and the bulk. As the surface becomes chlorinated, the chlorine atoms diffuse into the bulk and surface oxygen is regenerated. It is therefore viable to assume that the same process occurs when the surface becomes chlorinated as a result of the dehydrochlorination reaction.

The surface composition of $\mathrm{LaOCl}$ and $\mathrm{La}_{2} \mathrm{O}_{3}$ before and after reaction was determined with XPS. All spectra were normalized to the La3d band. Because lanthanum oxide-based materials strongly adsorb $\mathrm{CO}_{2}$ and $\mathrm{H}_{2} \mathrm{O}$, the exposure to air may influence the characterization of $\mathrm{O}$ atoms. The intensity of the $\mathrm{Cl} 2 \mathrm{p}$ band was therefore chosen
Fig. 5 Intensity of $\mathrm{H}_{2} \mathrm{O}$ and $\mathrm{HCl}$ peak in the chromatograms of for the dehydrochlorination of $1,1,2-\mathrm{C}_{2} \mathrm{H}_{3} \mathrm{Cl}_{3}$ over $(\mathbf{a}) \mathrm{La}_{2} \mathrm{O}_{3}$ and (b) $\mathrm{LaOCl}$ at $400{ }^{\circ} \mathrm{C}$ as a function of time as shown in Fig. 4. $\left(\mathrm{GHSV}=2,000 \mathrm{~h}^{-1}\right.$, inlet concentration: $[1,1,2-$ $\left.\mathrm{C}_{2} \mathrm{H}_{3} \mathrm{Cl}_{3}\right]=3.2$ vol\%, $\mathrm{x}_{\mathrm{n}}=$ product unassigned based on GC and IR)
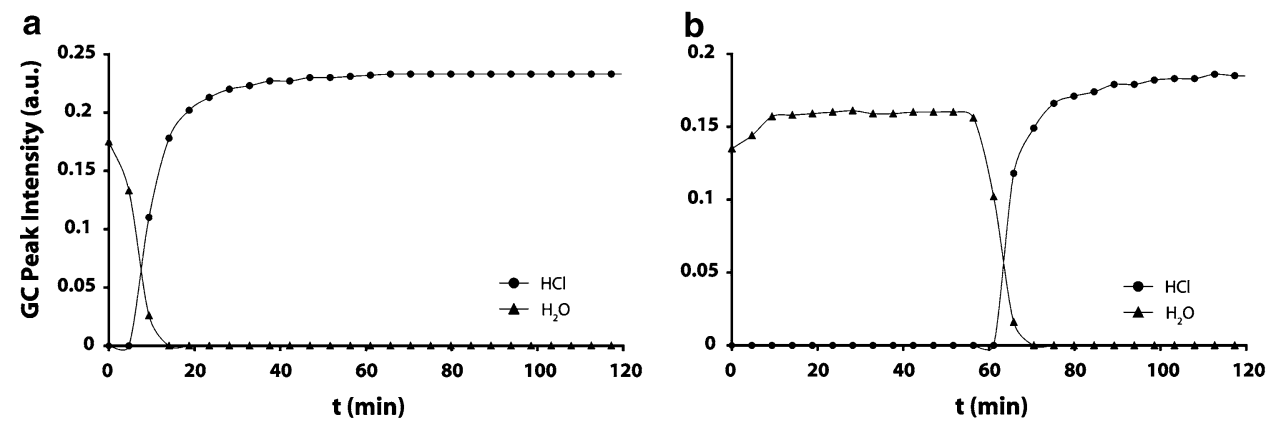


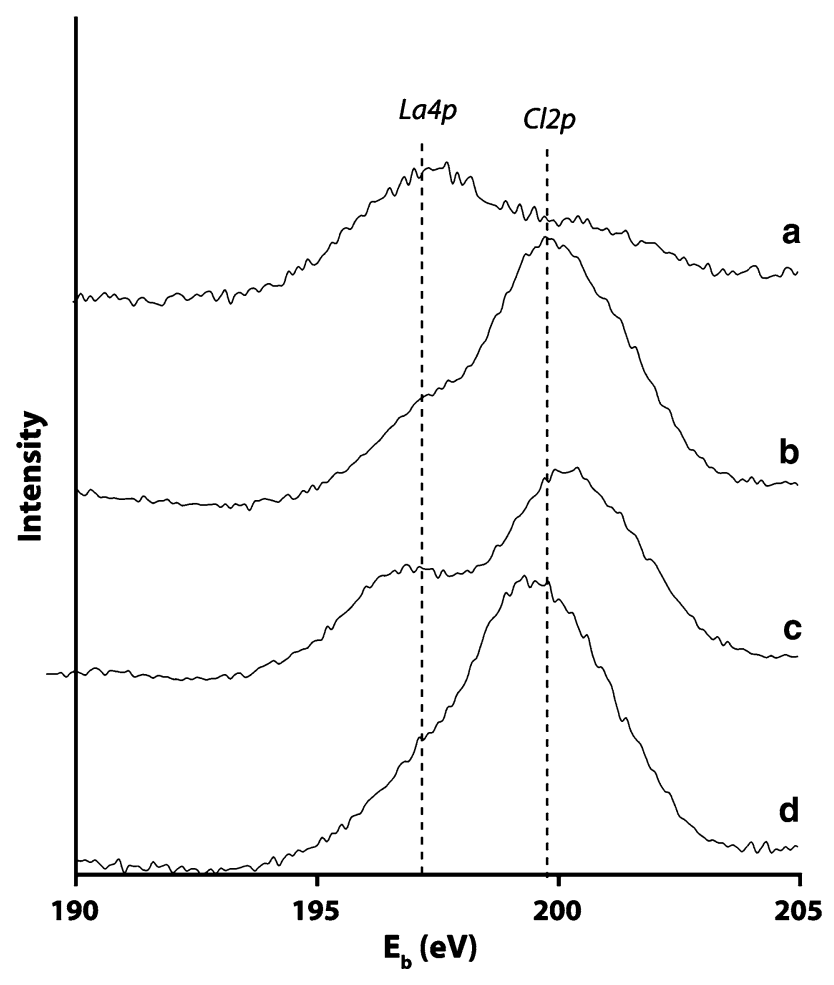

Fig. 7 X-ray photoelectron spectra of $\mathrm{La}_{2} \mathrm{O}_{3}$ and $\mathrm{LaOCl}$ before (a and $\mathbf{c}$, respectively) and after (b and $\mathbf{d}$, respectively) the dehydrochlorination of $1,1,2-\mathrm{C}_{2} \mathrm{H}_{3} \mathrm{Cl}_{3}$ at $400{ }^{\circ} \mathrm{C}$, as shown in Fig. 4

as a measure of surface chlorination. Figure 7 shows the $\mathrm{Cl} 2 \mathrm{p}$ band for $\mathrm{LaOCl}$ and $\mathrm{La}_{2} \mathrm{O}_{3}$ before and after reaction. The $\mathrm{Cl} 2 \mathrm{p}$ band is obviously not observed in the spectrum of $\mathrm{La}_{2} \mathrm{O}_{3}$ before reaction (Fig. 7a). However, the La4p band is observed in the same region at $207 \mathrm{eV}$. Both these XPS bands are known to possess a shoulder at higher energy than the maximum, which is also observed here. The La4p band appears as a shoulder of the $\mathrm{Cl} 2 \mathrm{p}$ band in the spectra of the materials containing chlorine. The $\mathrm{Cl} 2 \mathrm{p}$ band positioned at $200 \mathrm{eV}$ is observed in Fig. 7b-d. The spectra show that the surface chlorination of the materials after reaction is approximately the same and in both cases higher than before reaction. This result confirms the hypothesis that a specific degree of chlorination is required to reach steady-state conversion.

\section{Conclusion}

Lanthanum oxide-based materials are active catalysts for the dehydrochlorination of chlorinated ethanes. The reaction scheme for the dehydrochlorination of chlorinated ethanes over $\mathrm{La}_{2} \mathrm{O}_{3}$-based catalyst materials is schematically shown in Scheme 2. A hydrogen and chlorine atom is abstracted from the chlorinated ethane, resulting in the

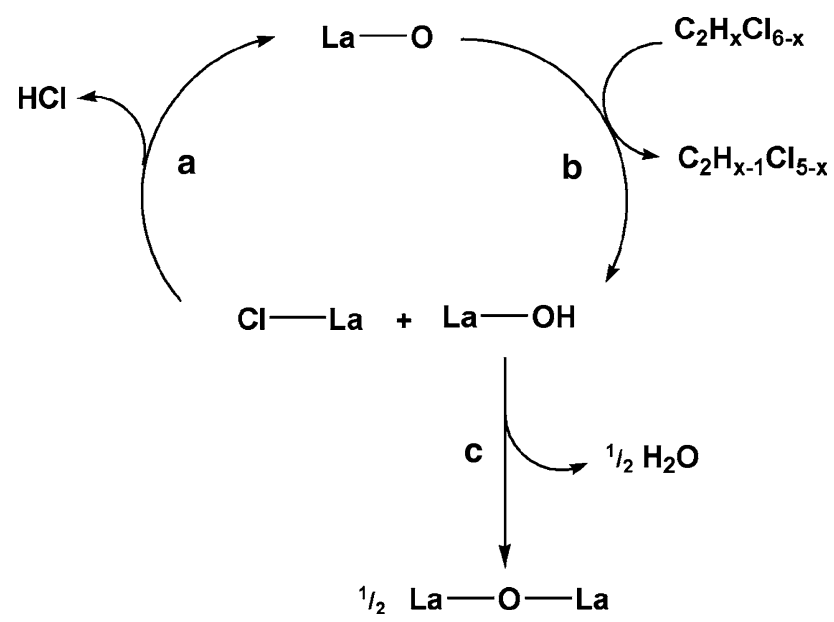

Scheme 2 Catalytic cycle for the dehydrochlorination of chlorinated ethanes over lanthanum oxide-based materials: (a) desorption of $\mathrm{HCl}$ from the catalyst material, (b) $\mathrm{H}+\mathrm{Cl}$ abstraction by catalytic surface and (c) desorption of $\mathrm{H} 2 \mathrm{O}$ from the catalyst material

formation of a hydroxyl group and a lattice chloride (Scheme 2, Reaction b). In the case of an O-rich surface, such as $\mathrm{La}_{2} \mathrm{O}_{3}$, the hydroxyl groups will react with other hydroxyl groups under formation of $\mathrm{H}_{2} \mathrm{O}$ (Scheme 2, Reaction c). However, when a specific degree of chlorination of the catalytic surface is reached, the elimination of $\mathrm{H}_{2} \mathrm{O}$ becomes less pronounced and $\mathrm{HCl}$ is formed according to Reaction a in Scheme 2. After the induction period characterized by the formation of $\mathrm{H}_{2} \mathrm{O}$, the product distribution and conversion become stable and the chlorination degree of the catalyst surface also remains constant.

The in situ IR experiments have shown that at relatively high temperature, secondary reactions may occur, such as a second dehydrochlorination step resulting in the formation of an ethyne, or destructive adsorption leading to the formation of $\mathrm{CO}$ and $\mathrm{CO}_{2}$. This indicates that the reaction temperature and chlorination degree are key factors to achieve optimal selectivity towards the formation of ethenes. Because the chlorination degree of the catalyst is of influence on both activity and selectivity for the conversion of chlorinated $\mathrm{C}_{1}$ and $\mathrm{C}_{2}$, it may be used to tune the catalytic properties of the $\mathrm{La}_{2} \mathrm{O}_{3}$-based catalyst. This control of activity and selectivity is crucial for the efficient conversion of chlorinated waste streams, such as the light ends in the production of $\mathrm{C}_{2} \mathrm{H}_{3} \mathrm{Cl}$.

Acknowledgments This work was supported by the National Research School Combination Catalysis (NRSCC) and an NWO-CW VICI Grant.

Open Access This article is distributed under the terms of the Creative Commons Attribution Noncommercial License which permits any noncommercial use, distribution, and reproduction in any medium, provided the original author(s) and source are credited. 


\section{References}

1. Bartsch R, Curlin CL, Florkiewicz TF, Lüke B, Minz H-R, Navin T, Scannell R, Schmittinger P, Zelfel E (2000) Chlorine: principles and industrial practice. Wiley-VCH, Weinheim

2. US Environmental Protection Agency (EPA) (1990) The clean air act of 1990, a primer on consensus building. Government Printing Office, Washington

3. Intergovernmental Panel on Climate Change (1990) In: Houghton JT, Jenkins GJ, Ephraums JJ (eds) Climate change: The IPCC scientific assessment. Cambridge University Press, Cambridge

4. Ozone Secretariat United Nations Environment Programme (2006) Handbook for the montreal protocol on substances that deplete the ozone layer 7th ed. Secretariat of the Vienna convention for the protection of the ozone layer and the Montreal protocol on substances that deplete the ozone layer, Nairobi

5. Eurochlor. Industry Review 2004-2005, to be found under http://www.eurochlor.org/index.asp?page=605 (2007)

6. Schmidhammer L (1988) US Patent $4,754,088$

7. Erb J (1993) Environ Prog 12:243

8. Bae JW, Kim IG, Lee JS, Lee KH, Jang EJ (2003) Appl Catal A 240:129

9. Bonarowska M, Malinowski A, Juszczyk W, Karpinski Z (2001) Appl Catal B 30:187

10. Hashimoto Y, Uemichi Y, Ayame A (2005) Appl Catal A 287:89

11. Legawiec-Jarzyna M, Srebowata A, Karpinski Z (2003) React Kinet Catal Lett 79:157

12. Srinivas ST, Jhansi Lakshmi L, Lingaiah N, Sai Prasad PS, Rao PK (1996) Appl Catal A 135:201

13. Yuan G, Lopez JL, Louis C, Delannoy L, Keane MA (2005) Catal Commun 6:555

14. Decker S, Lagadic I, Klabunde KJ, Moscovici J, Michalowicz A (1998) Chem Mater 10:674

15. Ma X, Zheng M, Liu W, Qian Y, Zhao X, Zhang B (2005) Chemosphere 60:796

16. Chien YC, Wang HP, Yang YW (2001) Environ Sci Technol 35:3259

17. Danielsen KM, Gland JL, Hayes KF (2005) Environ Sci Technol 39:756

18. Erbs M, Hansen HCB (1999) Environ Sci Technol 30:307

19. Ma X, Zheng M, Liu W, Qian Y, Zhang B, Liu W (2005) J Hazard Mater 127:156

20. Liu GH, Wang JL, Zhu YF, Zhang XR (2004) Phys Chem Chem Phys 6:985
21. Tamai T, Inazu K, Aika K (2003) Chem Lett 32:436

22. Koper O, Lagadic I, Klabunde KJ (1997) Chem Mater 9:838

23. Koper O, Li YX, Klabunde KJ (1993) Chem Mater 5:500

24. Klabunde KJ, Stark J, Koper O, Mohs C, Park DG, Decker S, Jiang Y, Lagadic I, Zhang D (1996) J Phys Chem B 100:12142

25. Koper O, Wovchko EA, Glass JA, Yates JJT, Klabunde KJ (1995) Langmuir 11:2054

26. Manoilova OV, Podkolzin SG, Tope B, Lercher JA, Stangland EE, Goupil JM, Weckhuysen BM (2004) J Phys Chem B 108: 15770

27. Podkolzin SG, Manoilova OV, Weckhuysen BM (2004) J Phys Chem B 109:11634

28. Tamai T, Inazu K, Aika K (2004) Bull Chem Soc Jpn 77:1239

29. van der Avert P, Weckhuysen BM (2002) Angew Chem Int Ed 41:4730

30. van der Avert P, Podkolzin SG, Manoilova OV, de Winne H (2004) Chem Eur J 10:1637

31. van der Avert P, Weckhuysen BM (2004) Phys Chem Chem Phys 6:5256

32. Weckhuysen BM, Rosynek MP, Lunsford JH (1999) Phys Chem Chem Phys 1:3157

33. van der Heijden AWAM, Bellière V, Espinosa Alonso L, Daturi M, Manoilova OV, Weckhuysen BM (2005) J Phys Chem B 109:23993

34. van der Heijden AWAM, Garcia Ramos M, Weckhuysen BM (2007) Chem Eur J 13:9561

35. Milchert E, Pazdzioch W, Myszkowski J (1995) Ind Eng Chem Res 34:2138

36. Carmello D, Finocchio E, Marsella A, Cremaschi B, Leofanti G, Padovan M, Busca G (2000) J Catal 191:354

37. Mile B, Ryan TA, Tribbeck TD, Zammitt MA, Hughes GA (1994) Top Catal 1:153

38. Bozzelli J, Chen Y (1992) Chem Eng Comm 115:1

39. Anderson JR, McConkey BH (1968) J Catal 11:54

40. Frankel KA, Jang BW-L, Roberts GW, Spivey JJ (2001) Appl Catal, A 209:401

41. Mochida I, Uchino A, Fujitsu H, Takeshita K (1976) J Catal 43:264

42. Pouchet CJ (1989) Aldrich library of FT-IR spectra: vapor phase. vol 3. Aldrich Chemical Company, Milwaukee 